\title{
Preparation of weaning foods by replacing plant proteins with egg protein
}

\author{
Muhammad NAEEM ${ }^{1}$, MAHR-UN-NISA ${ }^{1}$, Nazir AHMAD ${ }^{1}$, Muhammad IMRAN ${ }^{1}$, Haseeb ANWAR ${ }^{2}$, \\ Muhammad Faisal MANZOOR ${ }^{3,4 *}$ (1)
}

\begin{abstract}
The present study was designed to prepare to wean food by replacing plant proteins with egg proteins. The weaning foods containing 14, 16 and $18 \%$ extruded soy proteins were replaced with $0,25,50,75$ and $100 \%$ egg proteins using whole egg powder. Physicochemical analysis of raw material and weaned products, water activity, bulk density, in vitro study for protein digestibility, color analysis, microbiological analysis, and sensorial evaluation. Protein content significantly $(\mathrm{p}<0.05)$ varied from $13.76 \%$ to $19.89 \%$ for formulated weaning foods with the highest value in $\mathrm{T}_{12}$. Treatment $\mathrm{T}_{5}$ and $\mathrm{T}_{11}$ exhibited minimum water absorption capacity $(1.86 \mathrm{~mL} / \mathrm{g})$ and maximum $(2.63 \mathrm{~mL} / \mathrm{g})$, respectively. Treatment $\mathrm{T}_{1}$ exhibited the highest $(0.76 \mathrm{~mL} / \mathrm{g})$ values of bulk density, while the treatment $\mathrm{T}_{7}$ and $\mathrm{T}_{12}$ had the lowest values $(0.69 \mathrm{~mL} / \mathrm{g})$. The maximum in vitro digestibility was observed in treatment $\mathrm{T}_{15}(83.8 \%)$ while the minimum (65.4\%) was observed in treatment $\mathrm{T}_{1}$. The sensorial evaluation results for all the treatments are significantly $(\mathrm{p}<0.05)$ varies with an overall acceptable score. Results indicate that the microbial loads also within acceptable limits. The weaning foods composite animal proteins can be a cost-effective and possible tool to overcome malnutrition among children in developing countries.
\end{abstract}

Keywords: Protein Energy Malnutrition (PEM); weaning food; vegetable protein; animal protein; nutrient digestibility.

Practical Application: This study aims to formulate complimentary instant food from locally accessible, underutilized components that will provide the needed nutritional demand for infants.

\section{Introduction}

World's population increase by over 9 billion and almost ten million people are determined to be protein or energy malnourished (Alexandratos \& Bruinsma, 2012). By 2050, it would be needed two times more food production as compared to recent food production worldwide to meet the demand of the times. Nutritionists and other scientists follow similar observations that animal and plant sources will play a more important role in fulfilling the increased future food and energy requirements worldwide (Alexandratos \& Bruinsma, 2012; Sass et al., 2020). Sufficient nutrition requirements through infancy and early childhood are necessary for the growth of a beach child's full human potential. It is fully noticed that the first 2 years of children's age is a "critical window" for the development of health, optimal growth, and behavioral improvement. When a child attains 2 years of age, it is quite challenging to change the stunting that has happened earlier (Bernard et al., 2016). The instant results of inadequate nutrition throughout these developmental years include significant delays in motor and mental growth and significant morbidity and mortality. So, this early stage of nutritional deficiency is associated with impairments in mind (Bernard et al., 2016; Martorell et al., 1994). Complementary feeding starts when mother milk individually no longer adequate to satisfy the nutritional demands of infants. So, that's why the other liquids and foods are required, accompanied by mother milk. Complementary feeding commonly starts at 6 months up to 24 months of age (United Nations Children's Fund, 1998). More than one-third of child mortality occurs due to nutrition deficiency and from extended severity of disease (Addis et al., 2013). In Pakistan, the most common forms of malnutrition are protein-energy malnutrition (PEM), vitamin A, iodine, and Iron deficiencies as recommended by UNICEF, 2014 also responsible for about one-half of deaths among children under five years (World Health Organization, 2014).

Fruits and vegetables possibly beneficial origins of micronutrients and can be used for the formulation of complementary foods. The quality of protein can be enhanced by the incorporation of foods from an animal source (Bernard et al., 2016; Roobab et al., 2020). Several types of weaning foods are marketed in Pakistan but due to high cost, only available for $30 \%$ of the infant community. Rural mothers, that's why to rely on accessible low-cost complementary foods to wean their children. These household foods may not provide the needed nutrients for the infant; hence the demand for substitute sources that will be increased which is affordable for everyone. Because of this 
nutritional issue, various approaches have been applied to form weaning food, by using the combination of locally accessible foods. This study aims to formulate complimentary instant food from locally accessible, underutilized components (egg powder, soybean meal, carrot powder, and rice flour) which will provide the needed nutritional demand for infants and will be available and affordable to all mothers.

\section{Materials and methods}

\subsection{Procurement of raw material and preparation of weaned products}

The raw material for the preparation of weaning foods was purchased from the supermarket in quantity needed and prepared accordingly. Three weaning products containing 14, 16 , and $18 \%$ of proteins were prepared. In each product, the plant proteins (soybean meal) were replaced with animal protein (egg proteins). The egg powder, soybean meal, rice flour, and carrot powder were prepared accordingly shown in Figure 1. To optimize it, $0,25,50,75$, and $100 \%$ proteins replacement was done as a treatment plan and ingredients composition is presented in Table 1.

\subsection{Extrusion process}

The powder of all ingredients mixed thoroughly was extruded using a co-rotating twin-screw extruder with a smooth barrel. The extruder consisting of independent zones and the effective cooking zone temperature was set in the range of $100-140^{\circ} \mathrm{C}$. The extruder parameters such as feed rate, moisture content, and screw speed were set to get the maximum yield of extruded weaning food. The attention was to determine the impact of extrusion variables moisture (17-25\%) and screw speed (170-250 rpm). Moisture and screw speed were the most influential variables affecting the extrusion of the product: their linear, quadratic, and interaction terms accounted for more than $50 \%$ of the variability in all responses. The expansion was observed maximum at severe conditions of low moisture and high screw speed. Feed rate had no significant impact on extrusion efficiency. Hence, the feed rate varied for optimum fill according to screw speed. The moisture content of the feed was adjusted by injecting water (approximately $50^{\circ} \mathrm{C}$ ) into the extruder with a pump. A variable speed die face cutter with four-bladed knives was used to cut the extrudates.

\subsection{Physicochemical analysis of raw material and weaned products}

The rice flour, soybean meal, carrot powder, egg powder, and weaned products were evaluated for proximate composition i.e. moisture content, crude protein, crude fat, crude fiber, and ash content according to the method described Association of Official Analytical Chemists (2006).

\subsection{Water activity}

The determination of water activity (aw) was done by using ROTRONIC HYGROSKOP DT (USA) by the method proposed by Zhang et al. (2017). The method was based on the principle of placing the samples in an airtight chamber. As long as the quantity of water in the samples was much larger than the quantity of

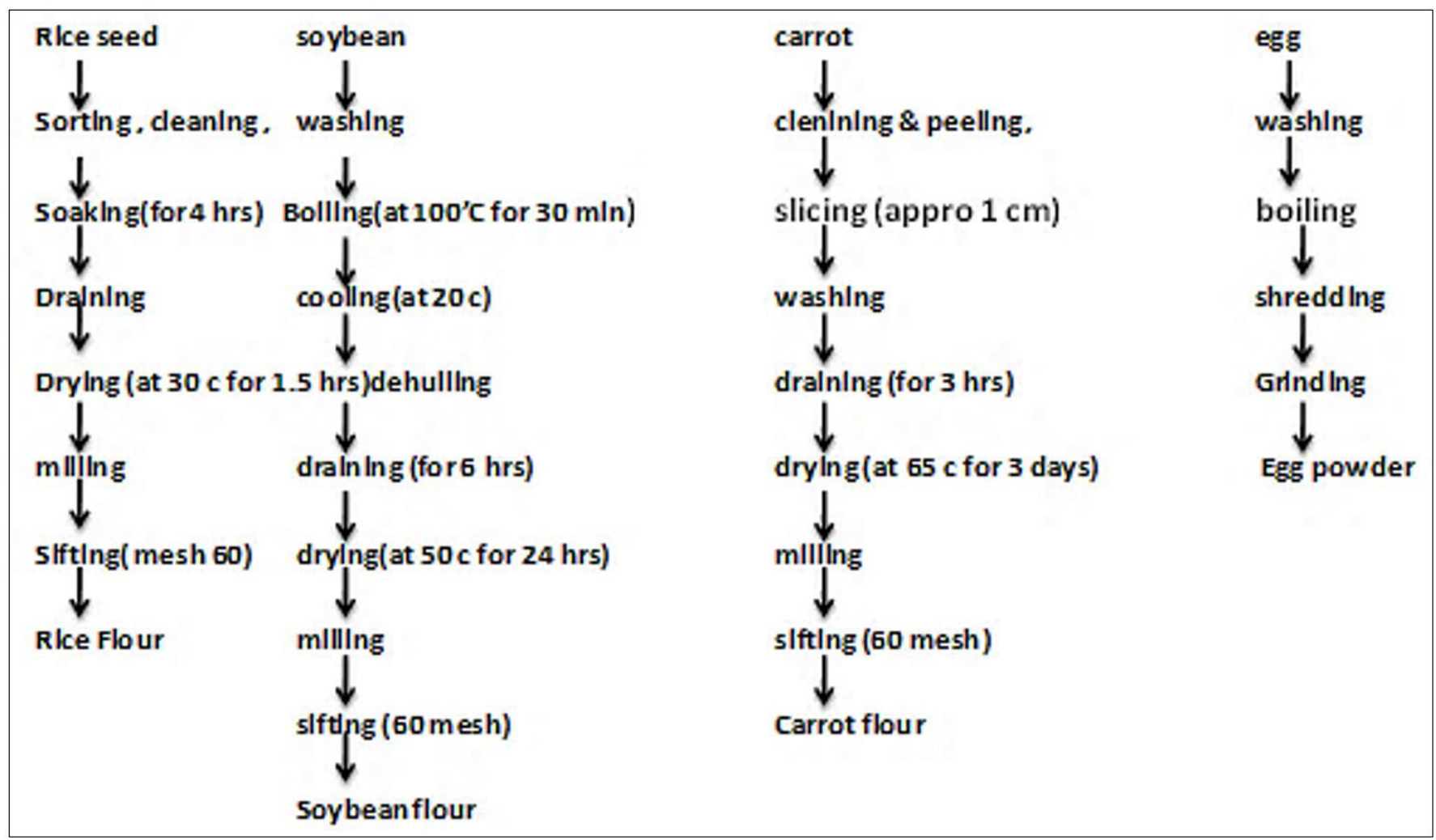

Figure 1. Schematic presentation of flours of rice, soybean, carrot, and egg prepared from raw materials. 
Table 1. Ingredients quantity (W/W) of weaned foods.

\begin{tabular}{|c|c|c|c|c|c|c|c|}
\hline $\begin{array}{l}\text { Protein } \\
\text { contents }\end{array}$ & $\begin{array}{l}\text { Replacement of } \\
\text { plant proteins }\end{array}$ & $\begin{array}{l}\text { Egg powder } \\
\text { (C.P 48\%) }\end{array}$ & $\begin{array}{l}\text { Soybean meal } \\
\text { (C.P 44\%) }\end{array}$ & Rice (C.P 8\%) & $\begin{array}{c}\text { Carrot Powder } \\
6 \%\end{array}$ & $\begin{array}{c}\text { Dextrose } \\
\text { monohydrate }\end{array}$ & Xanthan gum \\
\hline \multirow{3}{*}{$\begin{array}{l}14 \% \text { protein } \\
\text { contents }\end{array}$} & 0 & 0 & 22.72 & 50 & 16 & 10 & 0.5 \\
\hline & $50 \%$ & 10.48 & 11.36 & 50 & 16 & 10 & 0.5 \\
\hline & $75 \%$ & 15.62 & 5.68 & 50 & 16 & 10 & 0.5 \\
\hline \multirow{5}{*}{$\begin{array}{l}16 \% \text { protein } \\
\text { contents }\end{array}$} & $0 \%$ & 0 & 27.27 & 30 & 16 & 10 & 0.5 \\
\hline & $25 \%$ & 6.25 & 20.45 & 50 & 16 & 10 & 0.5 \\
\hline & $50 \%$ & 10.48 & 13.63 & 50 & 16 & 10 & 0.5 \\
\hline & $75 \%$ & 18.75 & 6.82 & 50 & 16 & 10 & 0.5 \\
\hline & $100 \%$ & 20.83 & 0 & 50 & 16 & 10 & 0.5 \\
\hline \multirow{3}{*}{$\begin{array}{c}18 \% \\
\text { proteins } \\
\text { contents }\end{array}$} & $50 \%$ & 14.58 & 15.90 & 50 & 16 & 10 & 0.5 \\
\hline & $75 \%$ & 23.95 & 7.95 & 50 & 16 & 10 & 0.5 \\
\hline & $100 \%$ & 29.16 & 0 & 50 & 16 & 10 & 0.5 \\
\hline
\end{tabular}

C.P: Crude protein.

water in the air of the chamber, the measurement will be more accurate and efficient. The water activity was calculated as ERH i.e. equilibrium relative humidity.

\subsection{Bulk Density (BD)}

The bulk density was measured by the method of Oladele \& Aina (2007) by using a standard bushel tester (Model 151, Seed buro Equipment Co, Chicago, IL, USA) and a test weight lifter cup and leveling stick (Model 103, Seed buro Equipment Co, Chicago, IL, USA).

\subsection{In vitro study for protein digestibility}

One milliliter of $11 \%$ trypsin was introduced in each test tube. After that, $4 \mathrm{~mL}$ of phosphate buffer was added at $7.5 \mathrm{pH}$ and $1 \mathrm{~mL}$ of HCL $(0.1 \mathrm{~N})$ was also added and allowed for some time to equilibrate. Then $1 \mathrm{~mL}$ of sample was added to each test tubes. After that, $5 \mathrm{~mL}$ of neutralized formalin was added to stop the reaction. The contents were filtered through sterilized filter paper. The nitrogen of the undigested sample was estimated through the Kjeldahl method (Equation 1).

In vitroprotein digestibility $(\%)=C P 1-C P 2 / C P 1$

Where $\mathrm{CP} 1=$ Total protein of sample; $\mathrm{CP} 2=$ Total protein of sample after digestion with trypsin.

\subsection{Color analysis}

The color analysis was performed according to the method described by Pathare et al. (2013) with the CIE lab (Hunter, Lab
Scan XE, USA) color scale with slight modifications. The color determination method was based on the Hunter $L^{*}, a^{*}$, and $b^{*}$ coordinates. Meanwhile, $L^{*}$ represents lightness and darkness, $a^{*}$ redness and greenness, $b^{*}$ yellowness, and blueness. The device was standardized against a white tile of Hunter Lab Color Standard (LX No.16379): $\mathrm{X}=77.26, \mathrm{Y}=81.94$, and $\mathrm{Z}=88.14$ ).

\subsection{Microbiological analysis}

For microbiological analysis, 1 gram sample of each product was dissolved in $9 \mathrm{~mL}$ of distilled water and the pour plate method was used. The malt extract and plate count ager was used for yeast \& mold and bacteria respectively. After the inoculation plates were incubated at $27^{\circ} \mathrm{C}$ for 3 days and $37^{\circ} \mathrm{C}$ for $48 \mathrm{~h}$ for yeast \& mold and bacterial growth respectively.

\subsection{Sensory evaluation}

The quality of different weaned food products was ranked according to the 9-point Hedonic scale (Meilgaard et al., 2007; Shahzad et al., 2020), through which the samples were assessed from the disliked extremely (1) to the liked extremely (9). The sensory evolution was carried out by 35 members of the Institute of Home and Food Sciences, Government College University, Faisalabad having aged $35-45$ years. The sensory evaluation was carried out under the illumination of $50-55 \%$ relative humidity and $25^{\circ} \mathrm{C}$.

\subsection{Statistical analysis}

The obtained results were subjected to statistical analysis using analysis of variance (ANOVA). Duncan's multiple range test was used to conclude statistically different groups. 


\section{Results and discussions}

\subsection{Proximate composition of raw material}

Figure 2 revealed that the proximate composition of different raw materials used for weaning food preparation. Maximum protein contents $(46.89 \pm 2.02 \%)$ were shown by whole egg flour and the lowest protein contents $(6.06 \pm 0.34 \%)$ were shown by carrot flour. Rice and soybean flour exhibited $(7.9 \pm 1.03 \%)$ and $(43.55 \pm 1.95 \%)$ protein contents respectively. Fat values of rice soybean egg and carrot were $(1.2 \pm 0.22 \%),(1.71 \pm 0.11 \%)$, $(8.99 \pm 0.78 \%)$ and $(2.01 \pm 0.14 \%)$ respectively. The highest fiber contents $(22.51 \pm 1.5 \%)$ were found in carrot while the lowest fiber contents were found in rice $(0.7 \pm 0.08 \%)$. Ash contents were found in $(6.1 \pm 0.98 \%)$ in soybean, $(4.97 \pm 0.3 \%)$ in carrot, $(2.74 \pm 0.32 \%)$ in egg and $(1 \pm 0.1 \%)$ in rice flour. Moisture percentage was varied among all materials (rice $=11.42 \pm 1.23 \%$, Soybean $=5.55 \pm 0.88 \%$, Egg $=5.01 \pm 0.95 \%$ and Carrot $=8.43 \pm 1.3 \%)$. Egg powder is highest in crude protein, and fat but lowest in dietary fiber and ash as compared to the soybean meal.

\subsection{Proximate analysis of weaning food}

The proximate composition of all weaning products presented in Table 2. The results reveal that the moisture contents of all prepared weaning products were inside the normal range of moisture contents (5-10\%) as described by FAO/WHO guidelines. Moisture contents were shown a variation among all treatments from $\mathrm{T}_{1}$ to $\mathrm{T}_{15}$ due to the different percentages of egg powder. Moisture contents ranged from $8.08 \%$ to $8.98 \%$ which indicated that the prepared food can be preserved for a long time. The flour and starch-containing materials having more than $12 \%$ moisture has limited shelf life than the lower moisture content products (Bernard et al., 2016). The ash content of food products gives an idea about mineral content and in present research; it varied from $1.92 \%$ to $3.21 \%$. The obtained results are comparable with the results published by Aderonke et al. (2014) for complementary diets prepared from soybean, maize, and pigeon pea. The results of the present study are in the recommended range, according to the Protein Advisory Group of the United Nations System (1972), the ash content of weaning foods should not exceed $5 \%$.

The fat contents of the formulated foods significantly $(p<0.05)$ varies from $1.31 \%$ to $3.54 \%$. The prescribed level of fat for formulated foods should not be higher than 10\% (Protein Advisory Group of the United Nations System, 1972) because if it's higher then it can influence the stability of the weaning foods. A food sample with higher fat contents more porn to spoilage because fat can undergo oxidative decay, which directs to spoilage and rancidification.

The obtained results indicate that the protein content significantly $(p<0.05)$ varied from $13.76 \%$ to $19.89 \%$ for formulated weaning foods. The highest protein contents were observed in $\mathrm{T}_{12}$ and followed by $\mathrm{T}_{14}$. According to WHO/FAO (Reddy et al., 1984), a minimum of $15 \%$ protein and a maximum of $25 \%$ is needed for the best complementation of amino acids in growth and foods (Sanni et al., 1999). So, our formulas satisfy the necessary demand for protein for infants.

Table 2 showed fiber contents increased as the protein $\%$ of soybean was replaced with egg protein. Maximum fiber $5.86 \%$ of contents were found in treatment $\mathrm{T}_{11}$ followed by $\mathrm{T}_{6}$. Minimum fiber contents of $4.12 \%$ were exhibited by treatment $\mathrm{T}_{5}$ and $\mathrm{T}_{10}$. Oche et al. (2017) explained in his study that crude fiber content in the formulated food of soybean and cereals

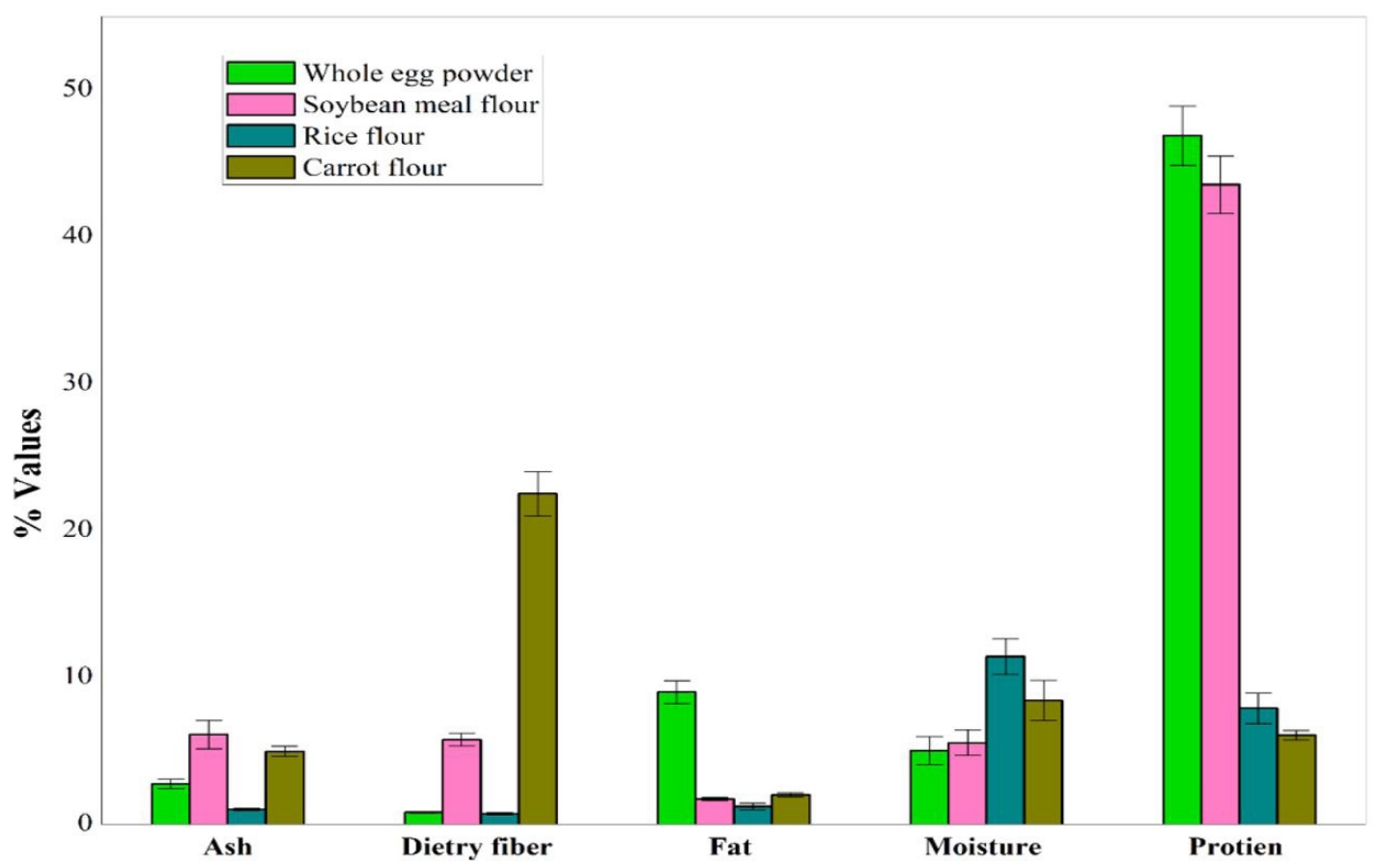

Figure 2. Proximate compositions of raw material powders. 
Table 2. Proximate analysis of weaning products (\%).

\begin{tabular}{|c|c|c|c|c|c|}
\hline Treatments & Ash contents & Fat contents & Moisture contents & Protein contents & Dietary fiber \\
\hline $\mathrm{T}_{1}$ & $2.66 \pm 0.03 c$ & $1.31 \pm 0.05 \mathrm{i}$ & $8.41 \pm 0.12 \mathrm{~d}$ & $14.16 \pm 0.19 \mathrm{e}$ & $5.31 \pm 0.06 \mathrm{ab}$ \\
\hline $\mathrm{T}_{2}$ & $2.48 \pm 0.04 \mathrm{~d}$ & $1.68 \pm 0.09 \mathrm{~g}$ & $8.33 \pm 0.14 \mathrm{e}$ & $13.76 \pm 0.22 f$ & $5.01 \pm 0.10 c$ \\
\hline $\mathrm{T}_{3}$ & $2.29 \pm 0.06 \mathrm{e}$ & $2.09 \pm 0.11 \mathrm{e}$ & $8.25 \pm 0.10 \mathrm{e}$ & $14.98 \pm 0.25 \mathrm{e}$ & $4.71 \pm 0.13 \mathrm{~d}$ \\
\hline $\mathrm{T}_{4}$ & $2.17 \pm 0.05 f$ & $2.44 \pm 0.13 \mathrm{~d}$ & $8.17 \pm 0.09 f$ & $14.96 \pm 0.17 \mathrm{e}$ & $4.41 \pm 0.11 \mathrm{de}$ \\
\hline $\mathrm{T}_{5}$ & $1.92 \pm 0.03 g$ & $2.79 \pm 0.07 c$ & $8.09 \pm 0.13 f$ & $14.95 \pm 0.12 \mathrm{e}$ & $4.12 \pm 0.05 \mathrm{e}$ \\
\hline $\mathrm{T}_{6}$ & $2.94 \pm 0.02 b$ & $1.47 \pm 0.05 h$ & $8.69 \pm 0.16 b$ & $16.81 \pm 0.18 c$ & $5.59 \pm 0.07 b$ \\
\hline $\mathrm{T}_{7}$ & $2.72 \pm 0.07 c$ & $1.89 \pm 0.02 \mathrm{f}$ & $8.57 \pm 0.12 c$ & $16.81 \pm 0.23 c$ & $5.23 \pm 0.02 \mathrm{ab}$ \\
\hline $\mathrm{T}_{8}$ & $2.43 \pm 0.06 \mathrm{~d}$ & $2.13 \pm 0.03 \mathrm{e}$ & $8.38 \pm 0.08 \mathrm{e}$ & $15.9 \pm 0.24 \mathrm{~d}$ & $4.85 \pm 0.04 \mathrm{~d}$ \\
\hline $\mathrm{T}_{9}$ & $2.27 \pm 0.08 \mathrm{e}$ & $2.74 \pm 0.07 c$ & $8.41 \pm 0.11 \mathrm{~d}$ & $16.78 \pm 0.15 c$ & $4.51 \pm 0.08 \mathrm{de}$ \\
\hline $\mathrm{T}_{10}$ & $1.92 \pm 0.02$ & $2.79 \pm 0.08 c$ & $8.08 \pm 0.18 f$ & $14.76 \pm 0.21 \mathrm{~d}$ & $4.12 \pm 0.10 \mathrm{e}$ \\
\hline $\mathrm{T}_{11}$ & $3.21 \pm 0.04 a$ & $1.55 \pm 0.05 h$ & $8.96 \pm 0.14 a$ & $18.97 \pm 0.09 b$ & $5.86 \pm 0.04 a$ \\
\hline $\mathrm{T}_{12}$ & $3.09 \pm 0.06 \mathrm{a}$ & $2.11 \pm 0.04 \mathrm{e}$ & $8.98 \pm 0.07 a$ & $19.89 \pm 0.13 a$ & $5.58 \pm 0.06 b$ \\
\hline $\mathrm{T}_{13}$ & $2.69 \pm 0.05 c$ & $2.55 \pm 0.09 \mathrm{~d}$ & $8.71 \pm 0.13 b$ & $18.82 \pm 0.17 \mathrm{~b}$ & $5.02 \pm 0.08 c$ \\
\hline $\mathrm{T}_{14}$ & $2.51 \pm 0.07 \mathrm{~d}$ & $3.23 \pm 0.06 b$ & $8.75 \pm 0.15 b$ & $19.73 \pm 0.12 \mathrm{a}$ & $4.62 \pm 0.07 \mathrm{~d}$ \\
\hline $\mathrm{T}_{15}$ & $2.17 \pm 0.08 \mathrm{f}$ & $3.54 \pm 0.11 \mathrm{a}$ & $8.51 \pm 0.12 c$ & $18.67 \pm 0.11 b$ & $4.18 \pm 0.12 \mathrm{e}$ \\
\hline
\end{tabular}

(2.64\%) is higher than the mean crude fiber in both proprietary formulae (1.74\%) and complies with Protein Advisory Group $(\mathrm{PAG})$ recommendation $(<5 \%)$. This implies that the formulated food will better promote laxation, bacterial colonization, and maturation of the gastrointestinal tract, but may interfere with mineral absorption more by adsorption (Temesgen, 2013).

\subsection{Water Absorption Capacity (WAC)}

Treatment $\mathrm{T}_{5}$ exhibited minimum WAC $(1.86 \mathrm{~mL} / \mathrm{g})$ while treatment $\mathrm{T}_{11}$ revealed maximum WAC $(2.63 \mathrm{~mL} / \mathrm{g})$ as shown in Table 3. During this study decrease in WAC was observed by increasing the protein \%. Echendu et al. (2004) reported that carbohydrates also affect the WAC of foods and the ability of a protein to water binding is also affects the WAC. They found a difference in WAC among all treatments possibly due to varying protein, carbohydrate concentration, and conformational properties (McWatters et al., 2003; Oliveira et al., 2020). These researchers also stated that lower WAC is associated with less availability of polar amino acids in formulated products. WAC as necessary for the consistency and bulking of the formulated product and also in baking applications (Niba et al., 2002; Sass et al., 2018). Achi (1999) stated an improvement in the WAC of the yam. In this study, the increase in WAC is may be associated with the water-binding qualities of egg albumin. McWatters et al. (2003) reported that the protein has both hydrophobic and hydrophilic characteristics and so can associate with water in foods.

\subsection{Bulk density of weaning food}

The obtained results in Table 3 indicate that the treatment $\mathrm{T}_{1}$ exhibited the highest $(0.76 \mathrm{~mL} / \mathrm{g})$ values of bulk densities, while the treatment $T_{7}$ and $T_{12}$ presented the lowest values $(0.69 \mathrm{~mL} / \mathrm{g})$. The trend was decreasing in bulk densities as
Table 3. Water absorption capacity and bulk density of weaning products.

\begin{tabular}{ccc}
\hline Treatments & $\begin{array}{c}\text { Water absorption capacity } \\
(\mathrm{mL} / \mathrm{g})\end{array}$ & Bulk density $(\mathrm{mL} / \mathrm{g})$ \\
\hline $\mathrm{T}_{1}$ & $2.41 \pm 0.05 \mathrm{ab}$ & $0.76 \pm 0.01 \mathrm{a}$ \\
$\mathrm{T}_{2}$ & $2.27 \pm 0.04 \mathrm{ab}$ & $0.73 \pm 0.02 \mathrm{a}$ \\
$\mathrm{T}_{3}$ & $2.12 \pm 0.07 \mathrm{bc}$ & $0.71 \pm 0.01 \mathrm{ab}$ \\
$\mathrm{T}_{4}$ & $2.02 \pm 0.02 \mathrm{c}$ & $0.70 \pm 0.03 \mathrm{ab}$ \\
$\mathrm{T}_{5}$ & $1.86 \pm 0.08$ & $0.75 \pm 0.02 \mathrm{a}$ \\
$\mathrm{T}_{6}$ & $2.53 \pm 0.01 \mathrm{a}$ & $0.72 \pm 0.01 \mathrm{a}$ \\
$\mathrm{T}_{7}$ & $2.37 \pm 0.07 \mathrm{ab}$ & $0.69 \pm 0.02 \mathrm{ab}$ \\
$\mathrm{T}_{8}$ & $2.22 \pm 0.03 \mathrm{~b}$ & $0.71 \pm 0.03 \mathrm{ab}$ \\
$\mathrm{T}_{9}$ & $2.11 \pm 0.09 \mathrm{c}$ & $0.73 \pm 0.01 \mathrm{a}$ \\
$\mathrm{T}_{10}$ & $1.91 \pm 0.06 \mathrm{c}$ & $0.75 \pm 0.02 \mathrm{a}$ \\
$\mathrm{T}_{11}$ & $2.63 \pm 0.04 \mathrm{a}$ & $0.71 \pm 0.01 \mathrm{ab}$ \\
$\mathrm{T}_{12}$ & $2.33 \pm 0.05 \mathrm{ab}$ & $0.69 \pm 0.03 \mathrm{~b}$ \\
$\mathrm{~T}_{13}$ & $2.29 \pm 0.03 \mathrm{ab}$ & $0.71 \pm 0.01 \mathrm{ab}$ \\
$\mathrm{T}_{14}$ & $2.18 \pm 0.04 \mathrm{~b}$ & $0.73 \pm 0.02 \mathrm{a}$ \\
$\mathrm{T}_{15}$ & $1.95 \pm 0.08 \mathrm{c}$ & $0.74 \pm 0.03 \mathrm{a}$ \\
\hline
\end{tabular}

presented in Table 3. Similar findings were also reported for yam by Hsu et al. (2003). Bulk density is a measure of heaviness observed in a food sample from normal behavior as also reported by Ak (2009). A significant characteristic that measures the appropriateness of food samples for the ease of packaging and transportation of particulate foods as well as for infant formulations is also focused in the present study. Nelson-Quartey et al. (2007) conducted a study and reported that low bulk density flours and/or food samples were desirable in infant food formulations. The low bulk density of the designed 
functional food, therefore, recommends that they would be beneficial for the health of infants and children.

\subsection{In vitro digestibility}

Protein digestibility values were estimated for each formulated food and results are shown in Figure 3. The maximum digestibility was observed in treatment $\mathrm{T}_{15}(83.8 \%)$ while the minimum (65.4\%) was observed in treatment $\mathrm{T}_{1}$ Digestion is a highly complex process providing animals with the energy and nutrients required for their maintenance and growth. For this reason, many researchers have been interested in the total or partial modeling of the digestion process using a variety of different in vitro methodologies. The in vitro approach has been used by nutritionists, who have tried to reproduce the physiological condition of the digestive tract, with a variable degree of accuracy, the compartments and working conditions existing in the digestive tract of the target species to have an insight on how feeds or food are processed or digested (Moyano et al., 2015). Almeida et al. (2015) manufactured the supplements by using whey protein and in vitro obtained their protein digestibility value in the range of 88.4 to $91.7 \%$. The protein digestibility is high about $89-96 \%$ in weaning foods formulated through rice and beans (Erbersdobler et al., 2017).

\subsection{Color characteristics}

The color properties of food products reveal the first impression before consumption and it's the first step of alike and dislikes for food products. The mean $L^{*}$ values for all treatments are significantly $(p<0.05)$ different and presented in Figure 4 . The treatment $\mathrm{T}_{11}$ exhibited the highest (85.02) values of lightness contents, while treatment $\mathrm{T}_{15}$ revealed the lowest

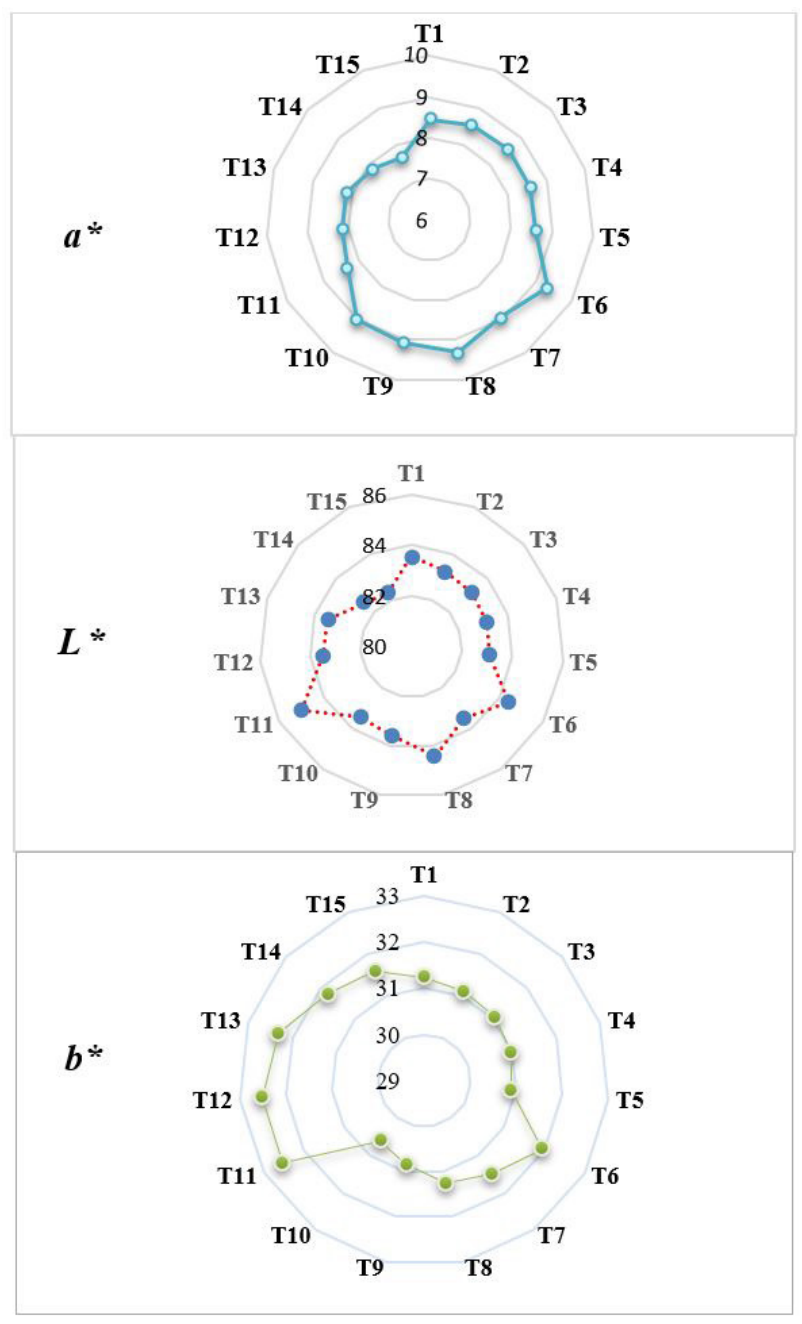

Figure 4. Optical properties of weaning products.

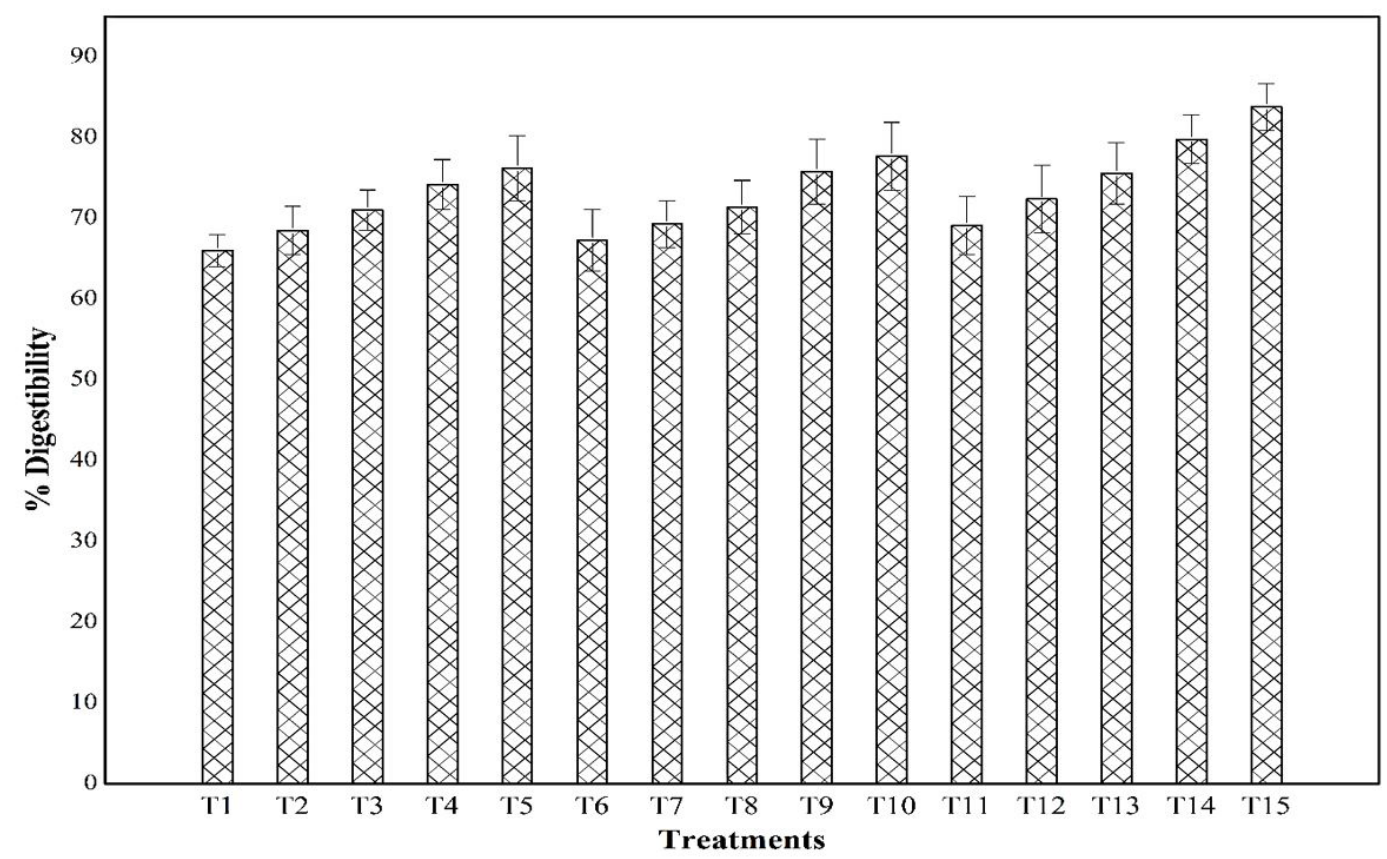

Figure 3. The in vitro protein digestibility values (\%) of weaning products. 
values (82.32). At $5 \%$ significant level $a^{*}$ values of prepared weaning food was manifested significant $(p<0.05)$ variation among all treatments. Figure 4 exhibited that redness contents increased as the soybean meal was replaced with egg powder. Maximum redness content (9.32) was found in treatment $\mathrm{T}_{8}$, while minimum (7.66) in $\mathrm{T}_{15}$. The mean $b^{*}$ values were significantly $(p<0.05)$ varies in all treatments. The highest

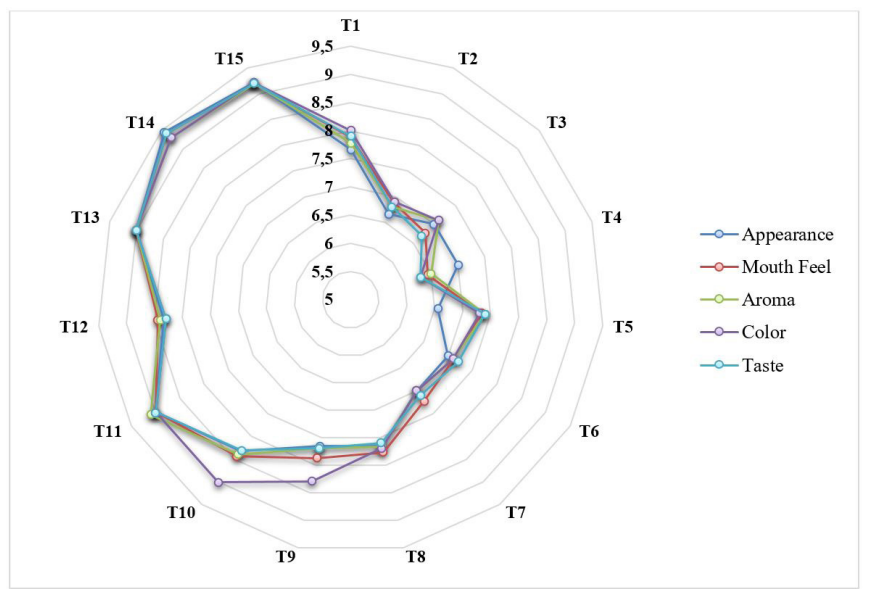

Figure 5. Sensory evaluation of weaning products. yellowness values (32.53) were observed in $\mathrm{T}_{11}$ and the minimum (30.9) was noted in $T_{5}$. Color value also showed the quantity of the suitable ingredients of the raw materials to be applied for the formulation and revealed informational data about the preparation and final quality of the product as indicated by the above observations. Bernard et al. (2016) conducted a study and reported that the variation in color properties in all weaning food formulations of egg and millet as well as other composite flours.

\subsection{Sensory analysis}

The sensory evaluation results for all the treatments are significantly $(p<0.05)$ varies and shown in Figure 5. The obtained results confirm the average likeness of the formed weaning foods for mouthfeel, appearance, color, taste, and aroma. The mean scores ranges of characteristics assessed were: taste (6.3 to 9.4), aroma (6.5 to 9.1), mouth feel (6.44 to 9.2), color (6.9-9.3), and appearance 7 to 9.44). Taste is an essential attribute when assessing the sensory characteristic of food. Because without a better taste food product is unacceptable, maybe a fascinating high energy density. The difference proportion of the protein in formulated weaning foods may have produced variation in

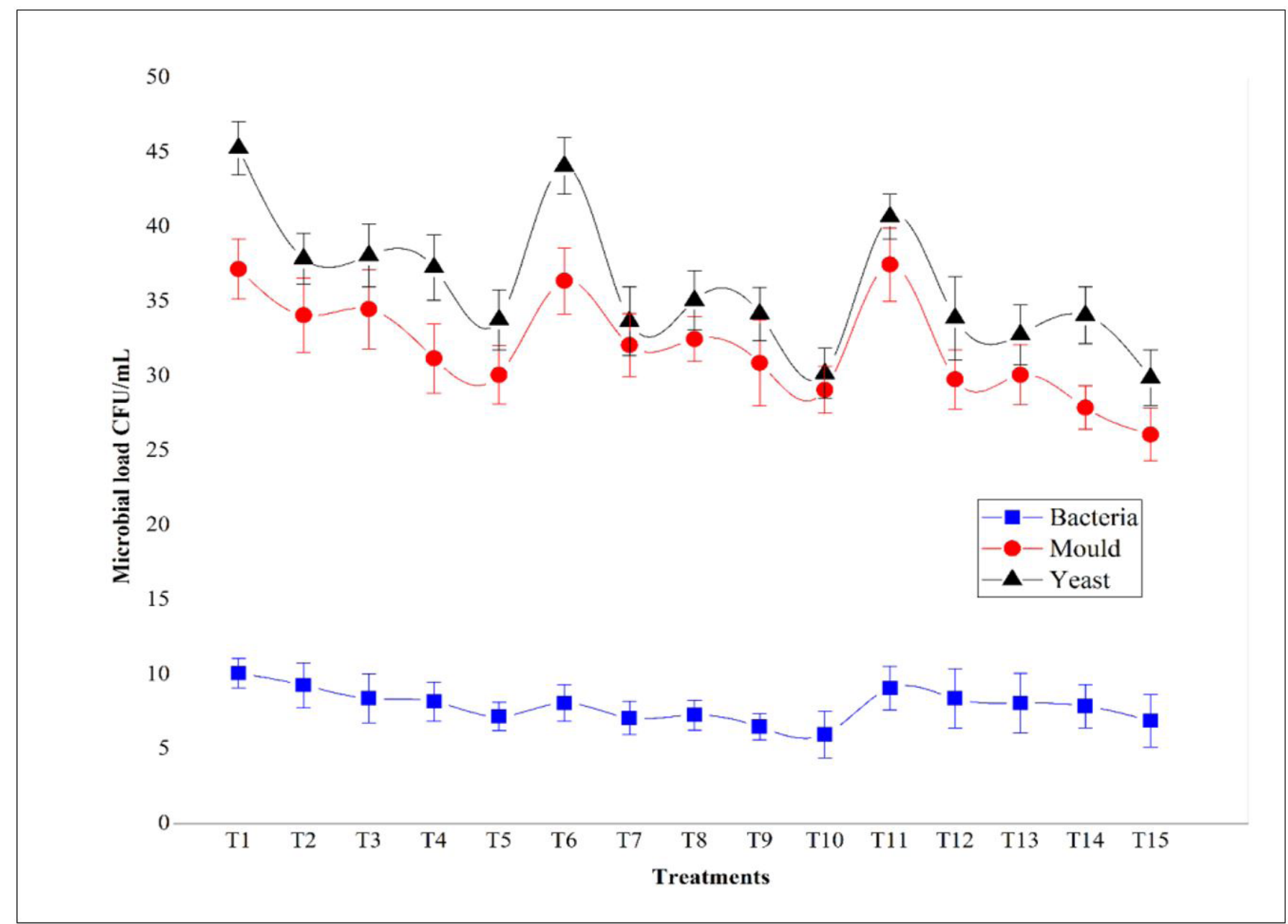

Figure 6. Microbial analysis of weaning products. 
taste. The formulated mixtures can sufficiently present the needed energy and protein level and consequently capable to give essential nutrients for the day's work and ultimately improve the problem of malnutrition (Bilsborough \& Mann, 2006). Usually, the mean sensory scores of all formulated foods with sugar were accepted showing that the addition of sugar not solely enhanced the energy density but also improved the flavor and color (Walker \& Pavitt, 1989). Martin et al. (2010) also reported similar results in research evaluating the acceptability of soybean-based weaning foods. Mitzner et al. (1984) reported that the processing (roasting) had a significant improvement in the formulated foods. Overall, the results confirm that our formulated weaning foods are of good quality. Similar findings were also been reported by Bernard et al. (2016) who reported that the taste values, flavor values, texture scores, and overall acceptability scores of all diets ranged between like slightly and like moderately.

\subsection{Microbial load}

Microbial analysis such as bacteria, mold, and yeast was done on freshly made weaning foods and results are exhibited in Figure 6. The obtained results indicate that a significant reduction in increasing the animal protein proportion. Yeast and mold counts were higher as compared to bacterial counts in all treatments. The maximum bacterial count $(10.1 \mathrm{CFU} / \mathrm{mL})$ was observed in $\mathrm{T} 1$ while the minimum $(6.0 \mathrm{CUF} / \mathrm{mL})$ was observed in treatment $\mathrm{T}_{10}$. The highest mold count was found in treatment $T_{1}$, while the lowest mold count was found in treatment $\mathrm{T}_{15}$ and a similar trend was observed for yeast count. For safe food consumption, the microbial count should be less than $1 \times 105 \mathrm{CFU} / \mathrm{g}$. The international microbiological standard suggests a bacterial count should be less than $106 \mathrm{CFU} / \mathrm{mL}$ for safe food consumption (Haefner, 2005). The less bacterial counts were acquired as a consequence of high extrusion temperature, better personal hygiene, and quality sustenance of good manufacturing practices followed during the formulation of weaning foods and raw material such as preparation of egg powder, rice flour, carrot powder, and soybean meal.

\section{Conclusion}

The possibility of occurring PEM during this transitional phase when children are weaned from liquid to semi-solid or fully adult foods where the growing body of children needs nutritionally balanced and calorie-dense supplementary food such as weaning foods in addition to mother's milk. The proximate compositions of all the extruded egg-based weaning products were varied significantly. Water absorption capacity was increased with increasing protein contents while bulk density decreased with an increasing percentage of egg powder. In vitro digestibility improved with increasing egg powder and a significant reduction in microbial load was observed with increasing the animal protein proportion. Yeast and mold counts were higher as compared to bacterial counts in all treatments. Based on the results, the replacement of egg proteins with legume proteins can be a cost-effective and possible tool to address malnutrition among children in developing countries.

\section{References}

Achi, O. (1999). Quality attributes of fermented yam flour supplemented with processed soy flour. Plant Foods for Human Nutrition, 54(2), 151-158. http://dx.doi.org/10.1023/A:1008130218830. PMid:10646561.

Addis, G., Singh, V., Pratape, V., Srivastava, A., Gowda, L., Asha, M., \& Bhattacharya, S. (2013). Development and functional properties of low-cost complementary food. African Journal of Food Science, 7(9), 274-284. http://dx.doi.org/10.5897/AJFS12.143.

Aderonke, A. M., Fashakin, J. B., \& Ibironke, S. I. (2014). Determination of mineral contents, proximate composition and functional properties of complementary diets prepared from maize, soybean and pigeon pea. American Journal of Nutrition and Food Science, 1(3), 53-56. http://dx.doi.org/10.12966/ajnfs.07.01.2014.

Ak, E. (2009). Some physicochemical properties of flour obtained from fermentation of tigernut (Cyperus esculentus) sourced from a market in Ogbomoso, Nigeria. African Journal of Food Science, 3(2), 51-55.

Alexandratos, N., \& Bruinsma, J. (2012). World agriculture towards 2030/2050: the 2012 revision. Rome: Food and Agriculture Organization of the United Nations.

Almeida, C. C., Monteiro, M. L. G., Costa-Lima, B. R. C., Alvares, T. S., \& Conte-Junior, C. A. (2015). In vitro digestibility of commercial whey protein supplements. Lebensmittel-Wissenschaft + Technologie, 61(1), 7-11. http://dx.doi.org/10.1016/j.lwt.2014.11.038.

Association of Official Analytical Chemists - AOAC. (2006). Official methods of analysis. Arlington: AOAC.

Bernard, T., Achidi, A., Noel, T., Bertrand, T. F., Marcel, M. N., \& Macaire, W. H. (2016). Nutritive value, functional and sensory attributes of weaning foods formulated from egg white, fermented maize, pawpaw and beans. American Journal of Food Science Nutrition Research, 3(3), 22-30.

Bilsborough, S., \& Mann, N. (2006). A review of issues of dietary protein intake in humans. International Journal of Sport Nutrition and Exercise Metabolism, 16(2), 129-152. http://dx.doi.org/10.1123/ ijsnem.16.2.129. PMid:16779921.

Echendu, C., Onimawo, I., \& Adieze, S. (2004). Production and evaluation of doughnuts and biscuits from maize-pigeon pea flour blends. Nigerian Food Journal, 22(1), 147-153.

Erbersdobler, H., Barth, C., \& Jah-reis, G. (2017). Legumes in human nutrition: nutrient content and protein quality of pulses. ErnährungsUmschau, 64(9), 134-139.

Haefner, J. W. (2005). Modeling biological systems: principles and applications. Boston: Springer Science \& Business Media. http:// dx.doi.org/10.1007/b106568.

Hsu, C.-L., Chen, W., Weng, Y.-M., \& Tseng, C.-Y. (2003). Chemical composition, physical properties, and antioxidant activities of yam flours as affected by different drying methods. Food Chemistry, 83(1), 85-92. http://dx.doi.org/10.1016/S0308-8146(03)00053-0.

Martin, H., Laswai, H., \& Kulwa, K. (2010). Nutrient content and acceptability of soybean based complementary food. African Journal of Food, Agriculture, Nutrition and Development, 10(1). http://dx.doi. org/10.4314/ajfand.v10i1.51482.

Martorell, R., Khan, L. K., \& Schroeder, D. G. (1994). Reversibility of stunting: epidemiological findings in children from developing countries. European Journal of Clinical Nutrition, 48(Suppl. 1), S45-S57. PMid:8005090.

McWatters, K. H., Ouedraogo, J. B., Resurreccion, A. V., Hung, Y. C., \& Phillips, R. D. (2003). Physical and sensory characteristics of sugar cookies containing mixtures of wheat, fonio (Digitaria exilis) and cowpea (Vigna unguiculata) flours. International Journal of Food 
Science \& Technology, 38(4), 403-410. http://dx.doi.org/10.1046/j.13652621.2003.00716.x.

Meilgaard, M., Civille, G., \& Carr, B. (2007). Overall difference tests: does a sensory difference exist between samples. Sensory Evaluation Techniques, 4, 63-104.

Mitzner, K., Scrimshaw, N. S., \& Morgan, R. (1984). Improving the nutritional status of children during the weaning period. Cambrigde: Massachussets Institute of Technology.

Moyano, F. J., Saenz de Rodriganez, M. A., Díaz, M., \& Tacon, A. G. (2015). Application of in vitro digestibility methods in aquaculture: constraints and perspectives. Reviews in Aquaculture, 7(4), 223-242. http://dx.doi.org/10.1111/raq.12065.

Nelson-Quartey, F. C., Amagloh, F., Oduro, I. N., \& Ellis, W. O. (2007). Formulation of an infant food based on breadfruit (Artocarpus altilis) and breadnut (Artocarpus camansi). In I International Symposium on Breadfruit Research and Development. Belgium: ISHS.

Niba, L., Bokanga, M., Jackson, F., Schlimme, D., \& Li, B. (2002). Physicochemical properties and starch granular characteristics of flour from various Manihot esculenta (cassava) genotypes. Journal of Food Science, 67(5), 1701-1705. http://dx.doi.org/10.1111/j.1365-2621.2002.tb08709.x.

Oche, I. C., Chudi, O. P.-A., Terver, U. S., \& Samuel, A. (2017). Proximate analysis and formulation of infant food from soybean and cereals obtained in Benue State, Nigeria. International Journal of Food Science and Biotechnology, 2(4), 106-113.

Oladele, A., \& Aina, J. (2007). Chemical composition and functional properties of flour produced from two varieties of tigernut (Cyperus esculentus). African Journal of Biotechnology, 6(21), 2473-2476. http://dx.doi.org/10.5897/AJB2007.000-2391.

Oliveira, C. H., Boiago, M. M., \& Guaragni, A. (2020). Effects of heat treatments and edible shell coatings on egg quality after storage at room temperature. Food Science and Technology, 40(Suppl. 1), 344-348. http://dx.doi.org/10.1590/fst.13019.

Pathare, P. B., Opara, U. L., \& Al-Said, F. A. (2013). Colour measurement and analysis in fresh and processed foods: a review. Food and Bioprocess Technology, 6(1), 36-60. http://dx.doi.org/10.1007/s11947-012-0867-9.

Protein Advisory Group of the United Nations System - PAG. (1972). PAG Bulletin (Vol. 2). New York: United Nations.

Reddy, N., Pierson, M., Sathe, S., \& Salunkhe, D. (1984). Chemical, nutritional and physiological aspects of dry bean carbohydrates: a review. Food Chemistry, 13(1), 25-68. http://dx.doi.org/10.1016/03088146(84)90026-8.

Roobab, U., Batool, Z., Manzoor, M. F., Shabbir, M. A., Khan, M. R., \& Aadil, R. M. (2020). Sources, formulations, advanced delivery and health benefits of probiotics. Current Opinion in Food Science, 32, 17-28. http://dx.doi.org/10.1016/j.cofs.2020.01.003.

Sanni, A. I., Onilude, A. A., \& Ibidapo, O. T. (1999). Biochemical composition of infant weaning food fabricated from fermented blends of cereal and soybean. Food Chemistry, 65(1), 35-39. http:// dx.doi.org/10.1016/S0308-8146(98)00132-0.

Sass, C. A. B., Pimentel, T. C., Aleixo, M. G. B., Dantas, T. M., Cyrino Oliveira, F. L., Freitas, M. Q., Cruz, A. G., \& Esmerino, E. A. (2020). Exploring social media data to understand consumers' perception of eggs: a multilingual study using Twitter. Journal of Sensory Studies, 12607. In press. http://dx.doi.org/10.1111/joss.12607.

Sass, C., Kuriya, S., Silva, G., Silva, H., Da Cruz, A., Esmerino, E., \& Freitas, M. (2018). Completion task to uncover consumer's perception: a case study using distinct types of hen's eggs. Poultry Science, 97(7), 2591-2599. http://dx.doi.org/10.3382/ps/pey103. PMid:29660079.

Shahzad, M. A., Ahmad, N., Ismail, T., Manzoor, M. F., Ismail, A., Ahmed, N., \& Akhtar, S. (2020). Nutritional composition and quality characterization of lotus (Nelumbo nucifera Gaertn.) seed flour supplemented cookies. Journal of Food Measurement and Characterization. In press.

Temesgen, M. (2013). Nutritional status of Ethiopian weaning and complementary foods: a review. Open Access Scientific Reports, 2(2), 1-9.

United Nations Children's Fund - UNICEF. (1998). Complementary feeding of young children in developing countries: a review of current scientific knowledge. Geneva: WHO.

Walker, A. F., \& Pavitt, F. (1989). Energy density of Third World weaning foods. Nutrition Bulletin, 14(2), 88-101. http://dx.doi. org/10.1111/j.1467-3010.1989.tb00315.x.

World Health Organization - WHO. (2014). Global nutrition targets 2025: breastfeeding policy brief. Geneva: WHO.

Zhang, L., Sun, D.-W., \& Zhang, Z. (2017). Methods for measuring water activity (aw) of foods and its applications to moisture sorption isotherm studies. Critical Reviews in Food Science and Nutrition, 57(5), 1052-1058. http://dx.doi.org/10.1080/10408398.2015.1108 282. PMid:26517668. 